\title{
Palestine and Israel Representation in the National and International News Media: A Critical Discourse Study
}

\author{
Suwarno; Wening Sahayu \\ Universitas Negeri Yogyakarta, Indonesia \\ Corresponding Author: suwarno@polibatam.ac.id
}

\begin{abstract}
Despite a myriad of studies that have been reported in analysing media discourse, few works take into account media bias. In response to this empirical gap, the present critical discourse study (CDS) aims to expose how the biggest national and international news media, The Jakarta Post and The New York Times construct the media bias in depicting Palestine and Israel regarding the latest conflicts in 2019 and 2020. The transitivity system of Halliday's systemic functional linguistics (SFL) was adopted to examine the textual features or choice of words in the clauses of 4 news articles from each news media. The findings show that both mainstream media have similarities, as if more favors to Palestine as the victim of the conflicts rather than Israel as a war criminal nation. However, The Jakarta Post and The New York Times have different sensitivities in constructing media bias. This empirical evidence suggests that critical discourse analysis (CDA) has a pivotal role in comprehending language used in media discourses. The last but not least, combining CDA and another theoretical approach is suggested for future studies.
\end{abstract}

Keywords: critical discourse analysis; media bias; systemic functional linguistics; transitivity

\section{INTRODUCTION}

This article addresses the lack of study on media discourse under the umbrella of critical discourse studies that considering media bias. The news media around the world have played a pivotal role in disseminating information to audiences for a long time. Even now, the news stories produced by the media outlets have been very easily accessible in tandem with the development of digital technology. The media discourse essentially accommodates the information needs of multidisciplinary fields including education, entertainment, business, organization, politic, and the like. Behind the scene, the discourse of news media becomes the 'place where the relations of power are exercised and enacted' (Fairclough, 2015, p. 73). This means that either diction or the structures of clauses in the news articles can be modified to manipulate the contents and relations of the discourse.
With regard to the language of news reports, Fairclough (1995, p. 2) argued that news media has a 'power to influence the knowledge, beliefs, values, social relations, and social identities'. In this sense, the language used in a media discourse can lead the public opinion on a reported issue according to the hidden agenda. Paul and Elder (2006) asserted that in convincing and manipulating public society, the more sophisticated news sources enable them to produce an aura of unbiased news narration. Thus, the citizens' view of a matter is greatly influenced by news media except for certain people who can identify the media bias.

In terms of bias in media discourse, Paul and Elder (2006) mentioned that news media are influenced by several sensitivities in constructing the news story. First, sensitivity to advertisers, it leads to the profit of their 
business. News media tend to constructs stories in favor of advertisers as the main sources of revenue. Sensitivity to government is another aspect that shapes the news story. National news media, for instance, usually as the stateowned businesses that will always support government policies and avoid the stories that negatively feature the government. The third is sensitivity to powerful interests. This is associated with powerful groups' interests in taking care of a favourable public image. The news media itself, for instance, what the public society hopes, will have a deep influence in shaping news stories to win people's hearts. Sensitivity to their competitors is the last factor in constructing news stories. This is related to the competition among media outlets in reporting the news.

Regarding the sensitivities in making media bias, the biggest news media in Indonesia and the USA, i.e. The Jakarta Post and The New York Times, might have different views of this world including the conflict in Palestine. It is common knowledge that ideologically, Indonesia is closer to Palestine while America tends to support Israel. This phenomenon encourages the present study to analyse the news articles related to the feud between Palestine and Israel as disseminated by the major news providers from the two countries. Concerning the aforementioned issue, this study attempts to uncover how Palestine and Israel were represented within the discourse of online news reports broadcasted by The Jakarta Post and The New York Times.

In fact, news articles in media outlets cannot be analysed or judged literally. The present study adopts Critical Discourse Analysis (CDA) in terms of its point of view regarding the language and ideology (Fairclough, 2013) and the context of language use (Wodak, 2001). In general, CDA is defined by Van Dijk (2015, p. 466) as 'discourse analytical research that primarily studies the way social power abuse and inequality are enacted, reproduced, legitimated and resisted by text and talk in the social and political context'. As such, it is interesting when this approach has been applied to analyse the various objects such as political speech (see Firmonasari, Udasmoro, \& Mastoyo, 2020) and media discourse (Hidayah, 2020; Osisanwo, 2020; Sofyan \& Zifana, 2019; Tang, 2018). Furthermore, Fairclough (2013) revealed that CDA becomes the best method in analysing news article since it offers three-dimensional frameworks, namely description, interpretation, and explanation. Each of these stages should be implemented simultaneously in order to construct critical conclusion on discourse.

Besides, the theoretical framework of Halliday's systemic functional linguistic (SFL) was also adopted in this study for analysing the text of news stories.
O'Grady (2019) mentioned that 'critical linguistics using SFL as a tool to explicate the representation of bias in media discourse was very successful' (p. 466). For instance, functional grammar can analyse the language used on media discourse regarding the actions, speech, and thoughts so that the depiction of the agents can be elaborated (see Hidayah, 2020; Osisanwo, 2020). Halliday (1994) mentioned that the ways of language use (called as metafunction) are classified into three categories: ideational (representing reality or experience in the clause as representation), interpersonal (enacting social relationship in the clause as an exchange), and textual (presenting text and context in the clause as message). Grounded in SFL, Martin, Matthiessen, and Painter (1997) proposed the three systems as a guideline for analysing the meaning of clauses. (1) The theme system deals with the construction of the message and context of situation, (2) the mood system expresses the interaction or dialog between a speaker or writer and the audience, and (3) the transitivity system is concerned with the representation of actions and experiences in the meaning (Martin, Matthiessen \& Painter, 1997). Concerning to the aim of this study, the transitivity system is considered as the most proper tools to execute the analysis.

Halliday \& Matthiesen (2004) pointed out that the transitivity system itself has three major parts, namely process (concern about the action or happening), participants (discussion about who or what is involved in the action), and circumstance (information about where, when, why, and how the action occurs). These three items are viewed as the basic components to grammatically establish a clause. Under the part of the process system, Halliday \& Matthiessen (2004) claimed that process in this transitivity is classified into the six types: material process (the act of doing), mental process (the act of sensing/thinking), behavioral process (the act of behaving), verbal process (the act of saying), relational clause (the act of being and having), and existential clause (the act of existing).

Whilst related to the participant, the process is closely associated with the noun phrase of a clause. The overall relationship between processes and participants in the transitivity system is presented in Figure 1. Each of these processes has a different label on the participants that allows for distinguishing the function of each word. In the material process, for instance, the subject and object of the clause are called as "actor" and "goal" while in the verbal process is called as "sayer" and "receiver". Both of them are the same in terms of their grammatical role, but they have different functions in meaning. The actor deals with the action or the act of doing something, whereas 


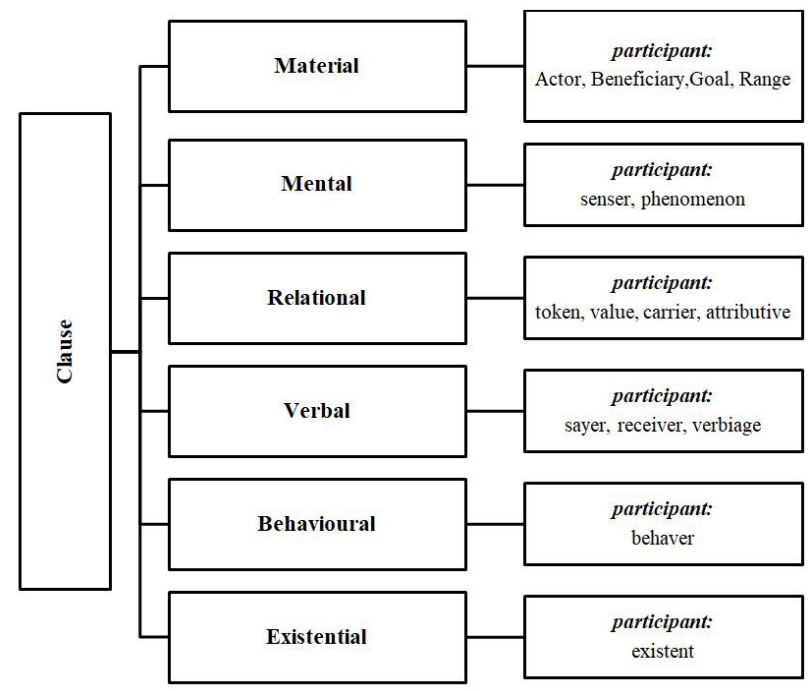

Figure 1. Processes and participants in transitivity system (adapted from Halliday \& Matthiesen, 2004).

the sayer is more related to speech or oral activity. Furthermore, circumstances are more likely to provide additional information so that the discussion adequately refers to the process and participants for in-depth analysis.

The following studies have applied the transitivity structures of Hallidayan SFL for analysing the media discourses. To begin with, Li (2011), who analysed news stories in The New York Times and China Daily regarding an air collision between China and the USA. The findings indicated that the socio-political tenseness between the two countries is shaped through transitivitymodeled news discourse. In a similar vein, a study by Seo (2013) explored the news of the Battle for Tripoli during the Libyan civil war of 2011 reported in online articles of British national daily newspaper The Guardian and the Chinese national daily newspaper, The People's Daily. Seo found the differences of ideologically-based choices and practices of these two newspapers regarding the global structure of political power.

Another relevant study by Tang (2018) examined three US newspaper agencies in representing China's image through published articles during 2008-2010. Informed by combining the corpus linguistics and transitivity system, the findings showed that China's image is represented consistently in a very negative light. Different from other previous studies, Osisanwo and Iyoha (2020) adopted Van Leeuwen's representation of social actors and transitivity system to examine the news reports of four Nigerian newspapers in portraying the pro-Biafra protest in 2015 and 2016. The findings indicated that the Nigerian news media are not neutral by representing the pro-Biafra protesters as violent, unruly terrorists and become a major threat to the economic growth of Nigeria. A recent critical discourse study by Hidayah (2020) looked into The Jakarta Post online news articles related to the Islamic Defenders Front (FPI) that protested the three issues: Ahmadiyah, the arrival of Lady Gaga in Indonesia, and Basuki Tjahaja Purnama's (Ahok) case. Hidayah found that FPI was framed as a group of anarchist protesters.

Grounded in transitivity structures and media bias, the present critical discourse study follows Fairclough's (2013) three dimensional frameworks (description, interpretation, and explanation) to analyse the representation of Palestine and Israel in the national and international media outlets. Data were garnered from online news articles published by The New York Times and The Jakarta Post between 2019 and 2020 which reported the conflicts in Palestine. Concerning the aforementioned frameworks and aim of this study, the discussion is conducted based on the following criteria:

1. The transitivity structures in the selected news articles;

2. The sensitivities of media bias in constructing the selected news articles.

In analysing data, the first step is description which involves the process of coding by labelling news texts based on transitivity features. Interpretation is the second step whereby the encoded texts are interpreted regarding the processes and participants that shape the discourse construction. Thus, the phenomena of discourse strategies that emerge in the news articles can be revealed. Finally, following Paul \& Elder's (2006) theory, the representations of Palestine and Israel are explained with regard to the sensitivities of media bias.

\section{FINDINGS AND DISCUSSION}

The discussion started with elaborating on the encoded data based on transitivity structures. All of the transitivity's process types (material, mental, relational, verbal, behavioral, and existential) were found in the selected news articles and grouped according to their publisher. As shown in figure 2, both of the news media have similarities of transitivity structures in constructing the selected news articles which are dominated by verbal and material processes. Verbal processes dominate the ratio of transitivity ones with $49 \%$ and $40 \%$, respectively. Material processes follows in the second rank with $15 \%$ and $23 \%$, respectively. This means that the dominance of verbal and material processes in the selected news articles can be a key to conclude the overall implied meaning. As 
Table 1. Participants of material and verbal processes in the selected news articles

\begin{tabular}{|c|c|c|c|c|c|}
\hline \multirow{2}{*}{ Mass media } & \multirow{2}{*}{ Processes } & \multirow{2}{*}{$\begin{array}{l}\text { Participants in material } \\
\text { and verbal processes }\end{array}$} & \multicolumn{3}{|c|}{ Number of findings } \\
\hline & & & Palestine & Israel & Neutral \\
\hline \multirow{6}{*}{ The Jakarta Post } & \multirow{4}{*}{ Material } & Actor & 2 & 6 & 2 \\
\hline & & Goal & 6 & 3 & 2 \\
\hline & & Range & 1 & 0 & 0 \\
\hline & & Beneficiary & 0 & 1 & 0 \\
\hline & \multirow{2}{*}{ Verbal } & Sayer & 3 & 20 & 11 \\
\hline & & Receiver & 0 & 0 & 3 \\
\hline \multirow{6}{*}{ The New York Times } & \multirow{4}{*}{ Material } & Actor & 7 & 16 & 5 \\
\hline & & Goal & 19 & 6 & 11 \\
\hline & & Range & 2 & 2 & 2 \\
\hline & & Beneficiary & 1 & 0 & 0 \\
\hline & \multirow{2}{*}{ Verbal } & Sayer & 14 & 30 & 22 \\
\hline & & Receiver & 5 & 1 & 3 \\
\hline
\end{tabular}

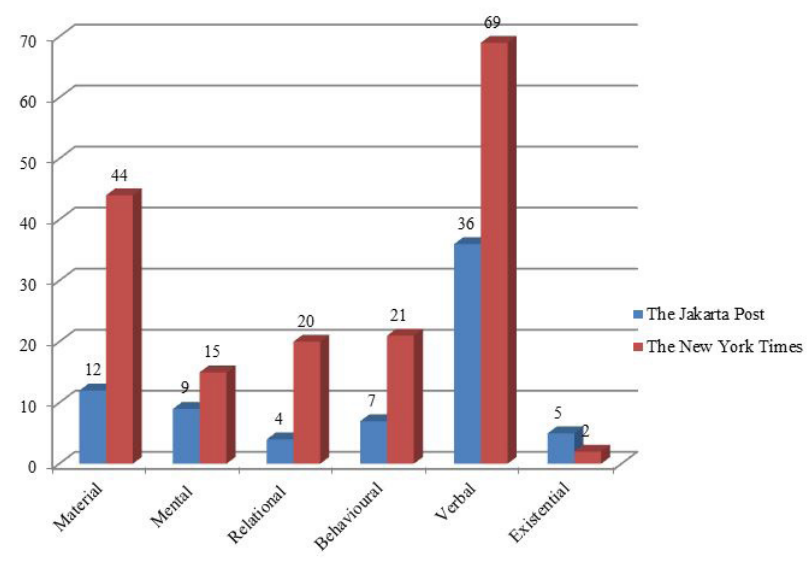

Figure 2. Transitivity structures in the selected news articles.

such, the discussion mainly focuses more on analysing the verbal and material processes as well as their participants.

The salient verbal and material processes in the discourse construction of the selected news reports show the dominance of speech (saying) and action (doing) clauses. Under the verbal clauses, Martin, Matthiessen, and Painter (1997) argued that the clauses are presented not only in various ways of saying (asking, offering, stating), but also in the process that is not perennially verbal (showing, indicating). As shown in Figure 1, the participants of the verbal process include "sayer", "receiver", and "verbiage". While the sayer deals with the participant who produces the utterance, the receiver is likely the addressee or receiver of the speech interaction. Then, the verbiage is the content of saying or can be identified as what the sayer is talking about. Put another way, verbiage may serve as the key element of verbal clause to identify the image of the sayer and receiver.

Table 1 shows the summary of sayers and receivers in the selected news articles and compares their occurrences in both sides, Palestine and Israel, so that statistically it can be distinguished easily. Moreover, the neutral side that is unrelated neither to Palestine nor Israel is also taken into accounts, such as United Nations officials, Human Rights officials, journalists, analysts, and banking executives. Informed by the number of participants in verbal clauses, both newspaper agencies have the same tendency in constructing the patterns of news reports. The structures of the verbal process showed that Palestine's image was nearly disguised. The numbers of verbal processes composed toward Palestine as far below that of Israel. On the other hand, Israel military and the government were reported more to speak up as sayers than verbal objects. The following excerpts illustrate the verbal patterns.

(VERBIAGE) "Islamic Jihad would do well to understand this right now, instead of when it will be too late," (SAYER) Mr. Netanyahu (VERBAL PROCESS) said at the start of a special cabinet meeting. (VERBIAGE) "I believe that Islamic Jihad is starting to internalize this message. They understand that we will continue to strike them without mercy. They understand that Israel is very strong and that our will is very great." (The New York Times, 13 November 2019, Paragraph 12). 
(VERBIAGE) An Israeli tank targeted a Hamas military post after the incident which began at around 2:00 am, (SAYER) Israel's military (VERBAL PROCESS) said (The Jakarta Post, 1 August 2019, Paragraph 2).

(VERBIAGE) Palestinian minister for Jerusalem affairs Fadi al-Hadami was detained and was being questioned for "activities in Jerusalem", (SAYER) Israeli police spokesman Micky Rosenfeld (VERBAL PROCESS) told (RECEIVER) AFP (The Jakarta Post, 20 June 2019, Paragraph 2).

In this sense, Israel deals more with verbal clauses indicating the high contribution of comments, declarations, intimidation, and claim through oral activities. These clauses show that The Jakarta Post and The New York Times likely portray the great involvement of the Israeli governments or military in prompting the war by quoting their warnings that at once showing strength toward Palestine. This means that Israel is pinned as an agent provocateur which has made worse of the atmosphere in the Middle East. Furthermore, in the contents of verbiage, Palestine is depicted more as less talkative and merely being accused. In some clauses, as sayer, Palestine tends to be constructed only for expressing their suffering.

In a speech on Wednesday night, (SAYER) Ziad al-Nakhala, the secretary-general of Islamic Jihad, (VERBAL PROCESS) said (VERBIAGE) that Israel was seeking a cease-fire and he laid out his group's conditions for one, including an end to Israel's targeted killings and a commitment to previous understandings on easing the blockade on Gaza (The New York Times, 13 November 2019, Paragraph 4).

(VERBIAGE) By midnight, the death toll in Gaza over the two days of violence had risen to at least 26, (VERBAL PROCESS) according to (SAYER) Palestinian health officials (The New York Times, 13 November 2019, Paragraph 5).

(VERBIAGE) The young man, identified as Mohammed Obeid, died of his wounds, (VERBAL PROCESS) according to (SAYER) the Palestinian health ministry (The Jakarta Post, 30 June 2020, Paragraph 12).

With regard to the negative contents of verbiage, the negative judgment and accusations on Palestine was frequently stated by Israel. Such appellations in terms like 'terrorism' and 'terror sites' were expressed unilaterally, as described in the following excerpts.

But (SAYER) the Israelis (VERBAL PROCESS) denounce (VERBIAGE) the practice as rewarding terrorism (The New York Times, 9 May 2020, Paragraph 4).

(VERBIAGE) In a new flareup a week ahead of fresh general election in the Jewish state, the Israeli Air Force carried out strikes on "Islamic Jihad terror sites" (SAYER) a military (VERBAL PROCESS) statement said (The Jakarta Post, 24 February 2020, Paragraph 2).

The discourse strategies showed that the lexical choices of the accusations were produced by the opposite parties. Thus, the structures have a less objective tone inasmuch as were not conveyed by neutral parties. On the contrary, there are many negative statements about Israel that were conveyed by neutral sayers, as showed in the following news article excerpts.

Despite Mr. Shtayyeh's efforts to defuse tensions, (SAYER) banking executives (VERBAL PROCESS) say (VERBIAGE) that there is no easy way around the order and that their institutions are compelled to stop dealing with the payment (The New York Times, 15 May 2020, Paragraph 13).

(VERBIAGE) Israeli soldiers committed violations of international human rights and humanitarian law. Some of those violations may constitute war crimes or crimes against humanity," (SAYER) the chair of the UN Independent Commission of Inquiry on the protests in the Occupied Palestinian Territory, Santiago Canton, (VERBAL PROCESS) said in a statement (The Jakarta Post, 28 February 2019, Paragraph 2).

(VERBIAGE) "The Commission found reasonable grounds to believe that Israeli snipers shot at journalists, health workers, children and persons with disabilities, knowing they were clearly recognizable as such," (SAYER) it (VERBAL PROCESS) said (The Jakarta Post, 28 February 2019, Paragraph 5).

The verbiages, as depicted above, seem to show the violence perpetrated by Israel against the Palestinian, both physically and economically. Drawing from the neutral sayer's statements, Palestinian identically was reported as a victim during the conflict. In this sense, objective judgments were more pronounced since uttered by the neutral parties. In other words, both of the news media 
seem to illustrate the alignments of the world community towards Palestine.

In terms of the material process, Martin, Matthiessen, and Painter (1997) explained that the material process covers both abstract and concrete actions. In general, material clauses present the process of doing that can be identified through the use of verbs that express any actions. Halliday \& Matthiessen (2004) contend that material clauses representing a happening can be called as intransitive (without participant as an object) while those typifying a doing is called as transitive (there is a participant as an object). Further, the concept of participant in material clauses is similar to the grammar role, such as subject and object. Martin, Matthiessen, and Painter (1997) classify participants in material clauses into four types, "actor, the one doing the material deed; goal, a participant impacted by a doing (done to/with); beneficiary, a participant benefiting from the doing (one given to or done for); and range, a participant specifying the scope of a happening" (p.103). Essentially, there are two participants in the material clause: actor as a doer (conducting an action) which is comparable with a subject, and goal which is equivalent to an object (receive an action). Drawing from Halliday's transitivity system, both of them are usually in the form of noun phrases which can be in either active voice (operative) or passive voice (receptive).

The summary of participants found in the material clauses is also provided in Table 1. The occurrences of Palestinian, Israeli, and neutral side as participants show several facts that could be drawn as findings. Overall, Israel was associated with more dominant as an actor rather than a goal. Israel was represented in the two news media with more action, the act of doing (doer) rather than receiving an action. On the other hand, Palestine appeared more as a goal rather than an actor. It was more clearly constructed by The New York Times with a significant difference in numbers of goals, 19 to 6 . This could be interpreted that this news media tried to create an image of Palestine likely to be the victims of the actions. While regarding the goal; Palestinian civilians were found to act as goals in a major proportion. It possibly means that the press agencies wanted to blow up the facts that many ordinary civilians or innocent people were being the victims of the conflict.

The Jakarta Post and The New York Times once again have similarities in constructing the selected news articles. With regard to the use of verbs in the news reports, Israel tend to be represented by verbs indicating violence of war and aggressiveness such as 'attack', 'killed', 'annexed', 'assassinate', 'shot', 'gunned', and 'force'. The following excerpts illustrate the action patterns.

(ACTOR) An Israeli soldier who (MATERIAL PROCESS) shot and killed (GOAL) a plainly unarmed Palestinian boy (The New York Times, 30 October 2019, Paragraph 1).

(ACTOR) Israel (MATERIAL PROCESS) assassinated (GOAL) an Islamic Jihad commander early Tuesday (The New York Times, 15 November 2019, Paragraph 4).

(GOAL) At least 297 Palestinians (MATERIAL PROCESS) have since been killed in Gaza or the border area (ACTOR) by Israeli fire (The Jakarta post, 1 August 2019, Paragraph 10).

These clauses suggest that Israel is the executor of shooting, killing, and assassinating toward his object or goal. In this case, the readers' mind would be filled with words related to scare or violence by the Israeli government and military. Conversely, the feeling of compassion and pity would be directed at Palestine as the object of violence. On the other hand, Palestine was represented in a less aggressive nature. The following news reports emphasize that Palestine did not start the war in the first place; instead, they just avenged the previous assassination of an Islamic Jihad commander.

(ACTOR) "Gaza militants (MATERIAL PROCESS) continued to bombard (GOAL) southern Israel with rockets on Wednesday and Israeli forces struck back against targets in the Palestinian coastal enclave in a clash set off by Israel's assassination of a senior Islamic Jihad commander on Tuesday" (The New York Times, 13 November 2019, paragraph 1).

Meanwhile, the choice of words and grammatical features can produce different interpretations. Fairclough (2013) explained that a critical analysis of language can be done through the analysis of vocabulary, grammar, and textual features. See the following excerpt:

At least (GOAL) 297 Palestinians (MATERIAL PROCESS) have since been killed in Gaza or the border area (ACTOR) by Israeli fire, the majority during demonstrations and clashes. (GOAL) Seven Israelis (MATERIAL PROCESS) have also been killed (The Jakarta post, 1 August 2019, paragraph $10)$.

The two sentences are the material process containing 
violence-related verbs, but employ different words and structures related to the actor. The former clearly showcases that Israel was the culprit of the murder incidents. It is directly shown through the phrase Israeli fire as the actor. On the contrary, despite showing a similar incident, the latter seems to camouflage the participation of Palestine by excluding the actor. There is no word or phrase that explicitly points out the involvement of Palestinians. Thus, it will lead to the readers' interpretations regarding which one is more salient as the executor. In this case, while Israel is explicitly mentioned as the performer of the incidents, Palestine is showed disguisedly.

Meanwhile, it is interesting to find that The New York Times also pursues double standard in constructing the selected news reports. While most of the news contents seem to empathize with Palestinians' suffering, other parts indicate the Israeli's justified reprisal.

Issuing a stern warning to Islamic Jihad, Prime Minister Benjamin Netanyahu said Israel was not looking for an escalation but would respond harshly to each rocket attack (The New York Times, 13 November 2019, paragraph 12).

Israel also pointed repeatedly to airstrikes that it said had killed militants in the act of firing or preparing to fire rockets but had kept collateral damage to a minimum (The New York Times, 15 November 2019, paragraph 6).

On the day Othman was shot, the Israeli military said its soldiers had "identified an attempt to breach the security fence and infiltrate into Israel from the northern Gaza Strip and fired to stop the attempt." (The New York Times, 30 October 2019, paragraph 6).

The news excerpts show that violence or abuses of the Palestinians by the Israelis were reported as an understandable. In this case, counterattacks, minimal damage caused, maintaining security, and the like were described as justified reasons. These evidences indicate that the awareness of media bias in preparing the news stories was influenced by various conflicts of interest.

Grounded in Paul and Elder's (2006) theory regarding four sensitivities of media bias, the phenomenon found in the material and verbal processes can be analysed in depth. The first aspect is sensitivity to advertisers. Advertising is the main consumer and source of income for mass media whereby their needs should be accommodated (Hahn, Lee \& Lee, 2016; Eberl, Wagner $\&$ Boomgaarden, 2016). In the coverages of conflict in
Palestine, the advertisers may take into account only the heated subject or popularity of news that can attract a large number of readers. Regardless of the contents and bias of the news reports, advertisers only focus on their own interests for advertising their products. In other words, there is no reason for advertisers to gear the news contents toward specific agenda. However, they just want to attract the attention of online news readership to notice what they advertise.

Sensitivity to the government is another factor in making media bias. As is well known, Israel is an ally of United States that is always supported and defended. Certainly, this political interest will influence the news providers in the country. In several news excerpts, The New York Times seems in line with the national interests by justify the acts of violence against Palestinians that perpetrated by Israelis. Yet, most of the media outlet's reports tend to blame Israel's action when the US government tried to defend the country. This means that the news media coverages have been influenced by different conflicts of interest. In contrast to The Jakarta Post, the narration in the news contents is directly proportional to the Indonesian ideology and foreign-policy which consistently seem support to Palestine. It is clear that so far Indonesia has always defended Palestine through the United Nations forum and humanitarian assistance, as proven through the following news headline and excerpt.

Indonesia will always stand with Palestine (The Jakarta Post, 26 June 2019, headline).

Indonesia's staunch support for Palestine is mandated by its 1945 Constitution. Its preamble, inter alia, says that "independence is the inalienable right of every nation; therefore, colonialization on earth must be abolished" (The Jakarta Post, 26 June 2019, paragraph 3).

Thus, sensitivity to government clearly influences the view of The Jakarta Post's editors and journalists in order to win support from their government.

Another case that influences the media bias is sensitivity to powerful interests. In a global news provider, the powerful interests may associate with media owners, readers, advertisers, public figures, organizations, and the like. Since the news report on the conflicts in Palestine that have caught the attention of people around the world, news providers will pay more attention from the readers' preferences. Indeed, all journalists are aware that they are writing for an audience (Paul \& Elder, 2006, p. 18). International support, including United Nations officials, Human Rights officials, and of course Indonesians who are 
predominantly Moslem has been directed more at people in Palestine. It can be proven through the verbiages which were conveyed by neutral parties. Therefore, through the media discourse strategies, both of the news media took the chance to win positive recognition and gaining approval from worldwide audiences as the readership.

The last matter is sensitivity to the competitors. Generally, every news provider competes to present news reports that can attract the audiences. Again, this is related to the readership that also intertwined with the advertisers. Mullainathan and Shleifer (2005) mentioned that media bias is determined by competition and audience or reader homogeneity. Further, Mullainathan and Shleifer (2005) suggest that heterogeneous readers caused highly competitive whereby the biases of media outlets tend to offset each other. Drawing from the explanation of sensitivity to readers as powerful interests, it can be argued that the readers of the coverages of conflicts in Palestine tend to be homogeneous. In other words, the readership homogeneity indicates the slightly competitive. This means that the media bias of the two news providers in the context of Palestine and Israel is lack connection with that of the competitors. Informed by the explication of the four sensitivities, the sensitivities to government and readers or audiences are proven to dominate the media bias written by The Jakarta Post and The New York Times in portraying Palestine and Israel.

\section{CONCLUSION}

Concerning the transitivity structures and media bias, the present critical discourse studies focuses on the representation of Palestine and Israel in The Jakarta Post and The New York Times coverages. By describing and interpreting the research findings through the transitivity system, the explanation for both news media's tendency in representing Palestine and Israel could be revealed. It was clear that both of the press agencies seem more favored Palestine rather than Israel, since most of the news contents represent Israel more as an agent provocateur and a war criminal nation, while Palestine is depicted as the victim of the conflicts. In depth, this is explicated through the media bias in the material and verbal processes dominating the transitivity process in the sample news articles. However, some parts of The New York Times coverages suggest that violence or abuses of the Palestinians by the Israelis were justified as reasonable reprisal.

In The Jakarta Post coverages, the sensitivity to government and the readers' interests are salient in constructing the similar representation of Palestine and
Israel. In this sense, the Indonesian ideology, foreignpolicy, and the general public as the readers who are predominantly Moslem deeply influential in determining media bias. Different from The New York Times coverages, as a global news provider, the national interests and the world-wide readers have led to the different media bias in constructing Israel's image.

Overall, this study offers some suggestions that might be useful. To the readers, objectivity in reacting to news content is highly required in order to avoid false information that might be caused by the propaganda of certain power, either political power or social power. In responding to the media discourse, readers should pay attention to the factors that can lead to media bias, such as political interest, advertiser, government intervention, competitor, and the like. By noticing these items, they are expected to comprehend what purposes the news is constructing. Further, the combination of CDA and another theoretical approach is suggested for future studies. For instance, corpus linguistics (CL) and CDA could be integrated as mix-method to examine social values, phenomena, and social processes in the media discourses (see Cheng, 2013)

\section{REFERENCES}

Abuheweila, I. \& Halbfinger, D. M. (2019, November 15). In Strike That Killed 5 Children, Israel Said It Took Out Gaza Militant. Now It Isn't Sure. The New York Times, Retrieved from https://www.nytimes. com/2019/11/15/world/middleeast/israel-gazacivilian-casualties.html? searchResultPosition=2

Agence France-Presse. (2019, August 1). Exchange of fire on Gaza border kills Palestinian, wounds 3 Israel soldiers. The Jakarta Post, Retrieved from https://www.thejakartapost.com/news/2019/08/01/ exchange-of-fire-on-gaza-border-kills-palestinianwounds-3-israel-soldiers.html

Agence France-Presse. (2019, June 30). Israel arrests Palestinian minister in Jerusalem. The Jakarta Post, Retrieved from https:/www.thejakartapost.com/ news/2019/06/30/israel-arrests-palestinian-ministerin-jerusalem.html

Agence France-Presse. (2020, February 24). Israeli warplanes hit Gaza, Syria after Palestinian rocket barrage. The Jakarta Post, Retrieved from https:// www.thejakartapost.com/news/2020/02/24/israeliwarplanes-hit-gaza-syria-after-palestinian-rocketbarrage-.html

Agence France-Presse. (2019, February 28). UN probe accuses Israel of possible crimes against humanity. The Jakarta Post, Retrieved from https://www. 
thejakartapost.com/news/2019/02/28/un-probeaccuses-israel-of-possible-crimes-against-humanity. html

Cheng, W. (2013). Corpus-Based Linguistic Approaches to Critical Discourse Analysis. In C. A. Chapelle (Ed.), The Encyclopedia of Applied Linguistics (pp. 1353-1360). Oxford: Blackwell. https://doi. org/10.1002/9781405198431.wbeal0262

Eberl, J.-M., Wagner, M., \& Boomgaarden, H. G. (2016). Party Advertising in Newspapers. Journalism Studies, 19(6), 782-802. https://doi.org/10.1080/14 61670x.2016.1234356

Fairclough, N. (1995). Media Discourse. London: Arnold. Fairclough, N. (2013). Critical Discourse Analysis: The Critical Study of Language. New York: Routledge.

Fairclough, N. (2015). Language and Power ( $3^{\text {rd }}$ edn.). Abingdon, UK: Routledge.

Firmonasari, A., Udasmoro, W., \& Mastoyo, Y. T. (2020). Understanding Secularism and National Identity in French Political Discourses. Humaniora, 32(2), 135-150. https://doi.org/10.22146/jh.v32i2.55450

Hahn, K. S., Lee, H.-Y., \& Lee, J. (2016). Media Bias. The International Encyclopedia of Political Communication, 1-9. https://doi. org/10.1002/9781118541555.wbiepc057

Halbfinger, D.M. (2019, October 30). Israeli Soldier Gets One-Month Sentence Over Killing of Gaza Teenager. The New York Times, Retrieved from https://www.nytimes.com/2019/10/30/world/ middleeast/othman-helles-killing-israel-soldier. html? searchResultPosition $=5$

Halliday, M.A.K. (1994). An introduction to functional grammar (2nd edn.). London: E. Arnold.

Halliday, M.A.K. \& Matthiessen, C. (2004). An Introduction to Functional Grammar (3rd edn.). London: Arnold.

Hidayah, S. N. (2020). Image Construction of Islamic Defenders Front in the Jakarta Post Online News. Humaniora, 32(2), 163-169. https://doi. org/10.22146/jh.v32i2.37626

Kershner, I. \& Abuheweila, I. (2019, November 13). Exchanges of Fire Continue Across IsraelGaza Border. The New York Times, Retrieved from https://www.nytimes.com/2019/11/13/ world/middleeast/israel-gaza-islamic-jihad. html? searchResultPosition=1

Li, J. (2011). Collision of language in news discourse: a functional-cognitive perspective on transitivity. Critical Discourse Studies, 8(3), 203-219. https:// doi.org/10.1080/17405904.2011.586231

Martin, J.R., Matthiessen, C.M.I.M., \& Painter, C. (1997).
Working with Functional Grammar. London: Arnold. Mullainathan, S., \& Shleifer, A. (2005). The Market for News. American Economic Review, 95(4), 10311053. https://doi.org/10.1257/0002828054825619

O'Grady, G. (2019). SFL and Critical Discourse Analysis. The Cambridge Handbook of Systemic Functional Linguistics, 462-484. https://doi. org/10.1017/9781316337936.020

Osisanwo, A., \& Iyoha, O. (2020). "We are not terrorist, we are freedom fighters": Discourse representation of the pro-Biafra protest in selected Nigerian newspapers. Discourse \& Society. Advance online publication (pp. 1-17). https://doi.org/10.1177/0957926520939687

Paul, R., \& Elder, L. (2006). The Thinker's Guide for Conscientious Citizens on How to Detect Media Bias \& Propaganda in National and World News ( $3^{\text {rd }}$ edn.). California: Foundation for Critical Thinking press.

Rachmianto, A. (2019, June 26). Indonesia will always stand with Palestine. The Jakarta Post, Retrieved from https:/www.thejakartapost.com/ academia/2019/06/26/indonesia-will-always-standwith-palestine.html

Rasgon, A., \& Najib, M. (2020, May 9). Israel Cracks Down on Banks over Payments to Palestinian Inmates. The New York Times, Retrieved from https://www.nytimes. com/2020/05/09/world/middleeast/israel-palestinianinmates-banks.html?searchResultPosition $=36$

Seo, S. (2013). Hallidayean transitivity analysis: The Battle for Tripoli in the contrasting headlines of two national newspapers. Discourse \& Society, 24(6), 774791. https://doi.org/10.1177/0957926513503267

Sofyan, A. N., \& Zifana, M. (2019). Representing social action in Indonesian: A case of Indonesian presidential race. Indonesian Journal of Applied Linguistics, 9(2), 252-262. https://doi.org/10.17509/ijal.v9i2.20216

Tang, L. (2018). Transitive representations of China's image in the US mainstream newspapers: A corpusbased critical discourse analysis. Journalism. Advance online publication (pp. 1-17). https://doi. org/10.1177/1464884918801116

Van Dijk, T. A. (2015). Critical Discourse Analysis. In D. Tannen., H. E. Hamilton., \& D. Schiffrin (Eds.), The Handbook of Discourse Analysis ( $2^{\text {nd }}$ edn.) (pp. 466485). Chicester, West Sussex: John Wiley and Sons. Inc.

Wodak, R. (2001). What CDA Is About- a Summary of Its History, Important Concepts and Its Development. In R. Wodak and M. Meyer (Eds.), Methods of Critical Discourse Analysis (pp. 1-13). London: Sage. 